Научная статья

УДК 811.512 .31 ’36

DOI: $10.18101 / 2305-459 X-2020-4-42-46$

\title{
КАУЗАТИВНЫЕ КОНСТРУКЦИИ В БУРЯТСКОМ ЯЗЫКЕ: СПОСОБЫ ВЫРАЖЕНИЯ
}

\author{
(C) Дадуева Елена Александровна \\ кандидат филологических наук, доцент, \\ Бурятский институт инфокоммуникаций (филиал) \\ Сибирский государственный университет телекоммуникаций \\ и информатики \\ Россия, 670005, г. Улан-Удэ, ул. Трубачеева, 152 \\ edadueva@yandex.ru
}

\begin{abstract}
Аннотация. Статья посвящена проблеме выражения каузативности в бурятском языке. Основной целью данной работы является анализ различных способов образования каузативных конструкций в бурятском языке. Так, в статье отмечается, что основными способами образования каузативных конструкций в бурятском языке служат монопредикативные и полипредикативные конструкции. Указывается, что при образовании монопредикативных конструкций одной из самых продуктивных дериваций является каузативация, так как в бурятском языке морфологические каузативы образуются практически от любого глагола аффиксальным способом. К значимым средствам выражения категории каузативности относятся и полипредикативные конструкции, где в качестве матричного предиката выступают каузативные глаголы волевого воздействия, а в роли предикатных актантов - причастия будущего времени с показателями аккузатива и притяжания. Утверждается, что одной из главных особенностей построения каузативных конструкций в бурятском языке является возможность взаимозамены монопредикативных и полипредикативных способов выражения.
\end{abstract}

Ключевые слова: каузативность; каузативный глагол; монопредикативная конструкция; полипредикативная конструкция; бурятский язык, каузативация; морфологический каузатив; матричный глагол; предикатный актант.

\section{Для цитирования}

Дадуева $E$. A. Каузативные конструкции в бурятском языке: способы выражения // Вестник Бурятского государственного университета. Язык. Литература. Культура. 2020. Вып. 4. С. 42-46.

Проблема каузативности в лингвистике остается обсуждаемой на протяжении уже многих лет, что связано с универсальностью данной фундаментальной функционально-семантической категории, которая применима для описания любого языка. Каузативность определяется как выражение причинно-следственных отношений, в которых воздействие субъекта или события вызывает ответное действие, состояние или изменение качества другого субъекта [8; 7; 2; 9 и др.]. Понятийное содержание категории каузативности реализуется в языках по-разному, уникальность или типологическая общность языков в выражении того или иного значения входит в основу описания языковых явлений на 
разных уровнях языковой системы на материале многих языков мира $[8 ; 1 ; 6$; 11; 10 и др.]. В бурятоведении вопросы каузативности также разрабатываются $[4 ; 5]$.

К одному из основных вопросов в теории каузативности относится изучение языковых средств, участвующих в образовании каузативных конструкций. Основными способами образования каузативных конструкций в бурятском языке служат монопредикативные и полипредикативные конструкции.

При образовании монопредикативных конструкций одной из самых продуктивных дериваций здесь является каузативация, так как морфологические каузативы образуются практически от любого глагола при помощи словообразовательных аффиксов.

Данный факт типологически ожидаем, так как бурятский язык относится к числу агглютинативных языков с развитой системой аффиксации. Маркерами бурятского морфологического каузатива выступают суффиксы. К их числу можно отнести такие аффиксы, как -га (-го, -гэ), -гаa (-гээ, -гоо, -гөө), -ха (-хэ,

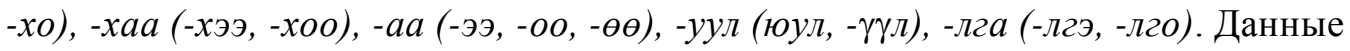
суффиксы в бурятском языке способны присоединяться к любым глагольным основам и образуют основное число каузативных глаголов. Например: ор-уул-ха 'ввести' от орохо 'войти', хэбт- $\gamma \gamma л-x э$ 'положить' от хэбтэхэ 'лежать ', зоб-оо-хо `мучить `от зобо-хо `мучиться ', хал-аa-ха `нагревать `от хала$x a$ 'нагреваться ', $x a m-a a-x a$ 'сушить 'от $x a m a-x a$ 'сохнуть 'и т. д.

1) Басага-яаа газаа яб-уул-ьиш!

Дочь-АСС улица отправить-CAUS-IMP

'Отправляй дочь на улицу!'

В бурятском языке также образуются морфологические каузативы и от таких категорийных единиц, как реципрок, социатив и рефлексив. Например: $x y$ -

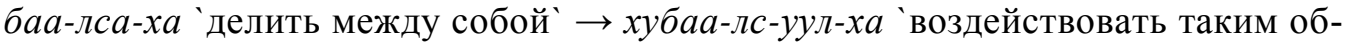
разом, чтобы делили между собой’, ала-лса-ха 'убивать сообща' $\rightarrow$ ала-лс-уул$x a$ `воздействовать таким образом, чтобы убивали сообща'. При такой каузативации наблюдается выражение значения социативной каузации [5].

Также стоит отметить факт существования в бурятском языке лексического способа выражения каузативного значения в монопредикативных конструкциях. И это несмотря на многообразие морфологических средств. Например, такие глаголы, как эмнэхэ 'лечить', алаха 'убить ', табиха 'ставить ', хааха ‘закрыть и др., содержат компонент «каузировать» в своем значении и не выражаются морфологическими средствами.

Во многих языках мира лексические каузативы образуются в процессе супплетивации (например, язык бодо) [10]. Известно, что супплетивация - это термин, используемый в морфологии для обозначения случаев, когда невозможно показать связь между морфемами через общее правило, потому что вовлеченные формы имеют разные корни. Супплетивация в парах бурятских каузативных и некаузативных глаголов также присутствует: табиха 'класть хэбтэхэ 'лежать', алаха 'убивать ' `вылечиться` и т. д. Например: 
2) Ши нам-айе үг-өөр ала-на-и

Tы-NOM я-ACC слово-INS убить-PRS-2.Sg

'Ты убиваешь меня словами'.

Полипредикативные конструкции в бурятском языке являются одним из значимых средств выражения категории каузативности. Такие конструкции содержат глаголы волевого воздействия и предикатные актанты. Матричным (вершинным) предикатом выступают такие каузативные глаголы со значением волевого воздействия, как гуйха 'просить', захиха 'заказать', уриха 'приглашать', аргадаха 'уговаривать', 'упрашивать'; 'молить', заабарилха 'велеть', захиха 'поручить', хорихо 'запрещать', эрихэ 'требовать', баалаха 'заставлять', дурадхаха 'советовать, предложить', Үнэниүүлхэ, этигүүлхэ 'убедить', захирха 'приказать' и др. В роли предикатных актантов выступают причастия будущего времени с показателями аккузатива и притяжания. Например:

3) Нам-айе ошо-х-ые-мни бү аргады-т!

\section{Я-AСС идти-PC.FUT-ACC-SG.1 не-NEG просить-IMP}

'Не просите меня идти!'

4) Марина аба-яа үлэ-х-ые-нь гуй-ба

Марина-NOM отец-ACC.REFL остаться-PC.FUT-ACC-3 просить-PST.

'Марина попросила отца остаться'.

Также отметим, что в число матричных глаголов могут включаться не только глаголы волевого воздействия. Например, Е. Я. Гордон приводит пример такого глагола в русском языке: Он сказал ему выйти [2]. Глагол сказал в таких конструкциях выступает синонимом каузативного глагола велеть, попросить (Он велел ему выйти). В бурятском языке также встречается употребление глаголов речи в роли матричных предикатов:

5) Эжы нам-да сонхо хам-х-ые-м хэлэ-бэ

Мать-NOM я-DAT окно-ACC закрыть-PC.FUT-ACC-SG.1 сказать-PST

'Мама велела мне закрыть окно'.

В бурятском языке мы выделяем также матричный предикат болгохо, который имеет значение, близкое к значению глагола заставить в русском языке. В сочетании с причастиями будущего времени болгохо выступает в значении «заставлять кого-либо делать что-либо»:

6) Дулм-ые ажал тухай хөөрэ-хэ бол-го-бо-бди

Дулма-АСС работа о рассказать-PC.FUT заставить- CAUS-PST-1.PL

'Мы заставили Дулму рассказать о работе'.

Отметим, что в бурятском языке полипредикативные каузативные конструкции можно заменить монопредикативными. Ср.: унша-х-ble-нь заa-хa `велеть читать' - унш-уул-ха `просить, велеть читать'; ерэ-х-ыле уриха 'просить

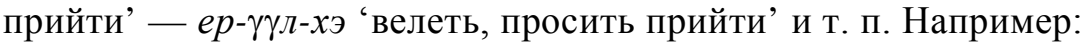

7) <.. > директор Жаргал-ые ерэ-х-ые-нь ури-ба

Директор-NOM Жаргал-АCС прийти-PC.FUT-ACC-3 пригласить-PST

'Директор попросил (позвал) Жаргала прийти' [ЭКБЯ. Г.-Д. Дамбаев. Эжын хоёр. 1982].

8) <...> Доржо университед-эйнгээ врач-ые ер-ҮҮл-бэ

Доржо-NOM университет-GEN врач-ACC прийти-CAUS-PST 
'Доржо попросил прийти (позвал) университетских врачей' [ЭКБЯ. Ч. Цыдендамбаев. Түрэл нютагһаa холо. 1958].

Мы видим в примере (7) полипредикативную конструкцию с каузативным глаголом волевого воздействия и причастием на -xa ерэ-x-ble уриха 'просить прийти', в примере (8) наблюдаем морфологический каузатив, используемый в

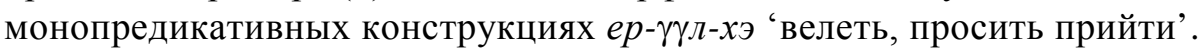

Таким образом, изучение способов выражения каузативных конструкций показывает, что в бурятском языке используются как монопредикативные, так и полипредикативные конструкции. Одной из главных особенностей построения каузативных конструкций в бурятском языке является возможность взаимозамены монопредикативных и полипредикативных способов выражения, что лишний раз доказывает, что бурятский язык обладает богатыми возможностями в выборе средств реализации семантики каузативности.

\section{Источники}

ЭКБЯ - Бурятский корпус (электронный корпус бурятского языка) [Электронный ресурc]. URL: http://web-corpora.net/BuryatCorpus/search/?interface_language=ru (дата обращения: 02.11.2020).

\section{Литература}

1. Абдиев Т. Конструкции с каузативными глаголами в киргизском языке. Бишкек, 2009. 114 с.

2. Гордон Е. Я. Каузативные глаголы в современном русском языке: автореф. дис. ... канд. филол.наук. Душанбе, 1981. 25 с.

3. Дадуева Е.А. Функционально-семантическая категория каузативности в русском и бурятском языках. Улан-Удэ: Изд-во Бурят. гос. ун-та, 2011. 128 с.

4. Дадуева Е. А. Каузативные конструкции с глаголами волевого воздействия в бурятском и русском языках // Сибирский филологический журнал. 2020. № 1. С. 267-277.

5. Дадуева Е. А., Харанутова Д. Ш. Социативная каузация в бурятском языке // Oriental Studies. 2019. 45(5):966-973.

6. Дистанова Г. М. Типология конструкций с каузативными глаголами в русском языке: автореф. дис. ... канд. филол. наук. Душанбе, 2010. 25 с.

7. Золотова Г. А., Онипенко Н. К., Сидорова М. Ю. Коммуникативная грамматика русского языка. М., 2004. 544 с.

8. Недялков В.П., Сильницкий Г. Г. Типология морфологического и лексического каузативов // Типология каузативных конструкций. Л.: Наука, 1969. 311 с.

9. Чудинов А. П. Семантическое варьирование русского глагола. Свердловск, 1984. 72 c.

10. Brahma D. Causative verb formation in bodo language // International Research Journal of Humanities, Language and Literature. 2017. Vol. 4, Issue 2, Febrary.

11. Shibatani M., Pardeshi P. The causative continuum // The Grammar of Causation and Interpersonal Manipulation [Typological Studies in Language], vol. 48, Masayoshi Shibatani (ed), Amsterdam: John Benjamins, 2002. Pp. 85-126. 


\title{
Условные обозначения грамматических значений в глоссах
}

ACC — винительный падеж; CAUS — каузативный глагол; DAT — дательный падеж; IMP — повелительное наклонение; INS — инструментальный падеж; NEG отрицание; NOM - именительный падеж, PC.FUT — причастие будущего времени; $\mathrm{Pl}$ - множественное число; SG - единственное число; PRS - настоящее время; PST — прошедшее время; REFL — показатели субъектного (возвратного) притяжания.

\section{CAUSATIVE CONSTRUCTIONS IN THE BURYAT LANGUAGE: WAYS OF EXPRESSION}

\author{
(C) Elena A. Dadueva \\ candidate of Philology, associate professor, \\ of the Buryat Institute of Infocommunications (branch) \\ of the Siberian State University of Telecommunications and Informatics in Ulan-Ude \\ edadueva@yandex.ru
}

Abstract. The article is devoted to the problem of expressing causativity in the Buryat language. The main purpose of this work is to analyze various ways of forming causative constructions in the Buryat language. Thus, the article notes that the main ways of forming causative constructions in the Buryat language are monopredicative and polypredicative constructions. It is indicated that in the formation of monopredicative constructions, one of the most productive derivations is causation, since in the Buryat language morphological causatives are formed from almost any verb in an affixal way. Significant means of expressing the category of causativity include polypredicative constructions, where causative verbs of volitional influence act as a matrix predicate, and future participles with indicators of accusative and possessive act as predicate actants. It is stated that one of the main features of constructing causative constructions in the Buryat language is the possibility of interchanging monopredicative and polypredicative ways of expression.

Keywords: causativity; causative verb; monopredicative construction; polypredicative construction; Buryat language, causation; morphological causative; matrix verb; predicate actant.

Статья поступила в редакичию 26.10.2020; одобрена после рецензирования 25.11.2020; принята к публикации 24.12.2020. 